\title{
THE USE OF PREDATORY MITE PHYTOSEIULUS PERSIMILIS (ACARI: PHYTOSEIIDAE) IN THE CONTROL OF TWO- SPOTTED SPIDER MITE (TETRANYCHUS URTICAE KOCH, ACARI: TETRANYCHIDAE) AT GREENHOUSE CUCUMBER PRODUCTION IN TOKAT PROVINCE, TURKEY
}

\author{
YANAR, D. ${ }^{1 *}-$ GEBOLOGLU, N. ${ }^{2}-$ CAKAR, T. $^{3}-$ ENGÜR, M. ${ }^{1}$ \\ ${ }^{1}$ Department of Plant Protection, Tokat Gaziosmanpaşa University, Tokat, Turkey \\ ${ }^{2}$ Department of Horticulture, Tokat Gaziosmanpaşa University, Tokat, Turkey \\ ${ }^{3}$ Bozok University, Agricultural Faculty, Department of Plant Protection, Yozgat, Turkey \\ (phone: +903562521616; fax: +903562521488) \\ *Corresponding author \\ e-mail:durdane.yanar@gop.edu.tr \\ (Received $27^{\text {th }}$ Oct 2018; accepted $11^{\text {th }}$ Jan 2019)
}

\begin{abstract}
The effectiveness of the predatory mite, Phytoseiulus persimilis Athias-Henriot (Acari: Phytoseiidae), as a suppressive agent of the two-spotted spider mite, Tetranychus urticae Koch (Acari: Tetranychidae), was evaluated on greenhouse cucumber at predator:prey release ratios of 1:5, 1:15, and 1:30. Releases at each predator:prey ratio were made at $30 \mathrm{~T}$. urticae densities per leaf. Evaluation was initiated 4 days after the release. On the under side of the leaves which were selected randomly from the lower, middle, and upper parts of the plants, the eggs and active forms of $T$. urticae and P. persimilis were counted using 10X hand magnifier for each treatment. In control treatments without predatory mite and acaricide application, population of T. urticae was constantly increased and reached 140 active forms/leaf in August. Subsequently the population decreased when the plants died. At ratios of 1:5, P. persimilis reached 8 active forms/leaf while T. urticae populations reached 11 active forms/leaf. At ratios of 1:15 $P$. persimilis population increased (3.4 active form per leaf) and T. urticae population decreased (1.6 active forms per leaf) in September and the latter one was kept by $P$. persimilis at low levels thereafter. Plant damage also was significantly reduced at these densities. $P$. persimilis population decreased when prey $(T$. urticae) population decreased. Our work demonstrates the potential of $P$. persimilis to provide effective control of $T$. urticae on a greenhouse-grown cucumber at a moderately low predator:prey ratio (1:15) in Tokat Province, Turkey.
\end{abstract}

Keywords: predatory mites, biocontrol, cucumber pests, spider mites

\section{Introduction}

Spider mites of the Tetranychidae are major pests of greenhouse cucumber and other agricultural crops worldwide. Foliar damage caused by spider mite feeding causes significant yield loss. To protect these plants from spider mite damage, farmers have traditionally relied on synthetic pesticides to suppress population outbreaks. However, due to resistance of spider mites to pesticides, negative effects of pesticides on natural enemies, and environmental concerns, other control tactics besides pesticides are needed.

An alternative to pesticides for suppression of spider mites is the inoculative release of predatory mites from the family Phytoseiidae. Predatory mites are important biological control agents of spider mites in many agricultural systems. Phytoseiids (Typhlodromus spp., Amblyseius spp., Phytoseiulus spp.) are effective at suppressing two-spotted spider mites in vegetables grown in greenhouse. Predatory mites have a shorter development 
periods and active feeding in each period, therefore they are very important biocontrol agents. In recent years, especially greenhouse vegetables and floriculture, as well as the control of the red spider species in the open field, primarily Phytoseiulus persimilis and other phytoseiid species have been used (Loginova et al., 1987; Jarasik, 1990; Jarasik and Pliva, 1990; Easterbrook, 1992; Zang and Sanderson, 1995; Boom et al., 2002; Lanzoni et al., 2017). Kim and Park (2006) reported that Tetranychus urticae was effectively controlled by the release of predatory mites at a rate of 3 predator $/ \mathrm{m}^{2}$. Limited studies were conducted in mass production of $P$. persimilis and it use in control of Tetranychus cinnabarinus on greenhouse growing strawberries (K1lınçer et al., 1992; Kazak et al., 1992; Öncüer et al., 1994; Kısmalı et al., 1999; Kazak et al., 2002; Çakmak et al., 2005; Çakmak et al., 2007) and cucumber (Kazak et al., 2000) in Turkey. In the study, conducted by Çakmak et al. (2005) reported that when the T. cinnabarinus population level reached 2-3 individuals per leaflet in strawberry plants, $P$. persimilis was released once at the rate of 1 predator to 20 prey, the predatory mites provided an effective control 15-20 days after release, and no additional release was needed during the rest of the growing season. At present, mass rearing of predator mite $P$. persimilis is not continued in Turkey. Commercial companies are exporting predator mites from abroad.

Aims of the present study is assess the effectiveness of the predatory mite Phytoseiulus persimilis at controlling two-spotted spider mite (Tetranychus urticae) when released into greenhouse growing cucumber plants in Tokat-Turkey.

\section{Materials and methods}

\section{Rearing predatory mites}

The stock cultures of Phytoseiulus persimilis were purchased from private company (Koppert Biological Systems, Netherland) and reared on the bean plants grown at $25^{\circ} \mathrm{C}$ and $60 \% \pm 5 \%$ relative humidity at $16 \mathrm{~h}: 8 \mathrm{~h}(\mathrm{~L}: \mathrm{D})$.

\section{Screenhouse trial}

The experiment was conducted in Plant Protection Department screenhouse at the Tokat Gaziosmanpasa University, Tokat. The screenhouse received natural light during the course of the treatment with no artificial light source or climate controls. Coco peat is used for growing cucumber plants (Figure 1). Necessary plant essentials were given by water dripplet system. The average temperature and relative humidity were $26 \pm 2{ }^{\circ} \mathrm{C}$ and $60 \pm 5 \%$ during the course of the experiment in the screenhouse. Five treatments were evaluated in an randomized complete block design with three blocks and nine plants per replicates. A predator:prey ratio of 1:5, 1:15; 1:30 was calculated for each release. In addition to this, there is a control and acaricide treatment with classical acaricide (Spiromesifen $240 \mathrm{~g} / \mathrm{l}$ (Oberon SC 240) $50 \mathrm{ml} / \mathrm{da}$ ) application. Thirty Tetranychus urticae young female were placed on individual plants with the aid of a fine-tipped saber brush. Two days after $T$. urticae release, at 1:5, 1:15, and 1:30 ratios 6, 2, and 1 mated young $P$. persimilis female individuals were released (Kazakoğlu et al., 2000). Acaricide was applied at recommended concentration.

Evaluation was performed 4 days after the predatory mite release. Plants were evaluated every four days. In each plot lower, middle and upper parts of randomly selected plants 25 leaves were visually assessed and the number of $T$. urticae and $P$. 
persimilis motiles and eggs counted with hand-held 10X magnifier to quantify the effect of $P$. persimilis releases on $T$. urticae populations.
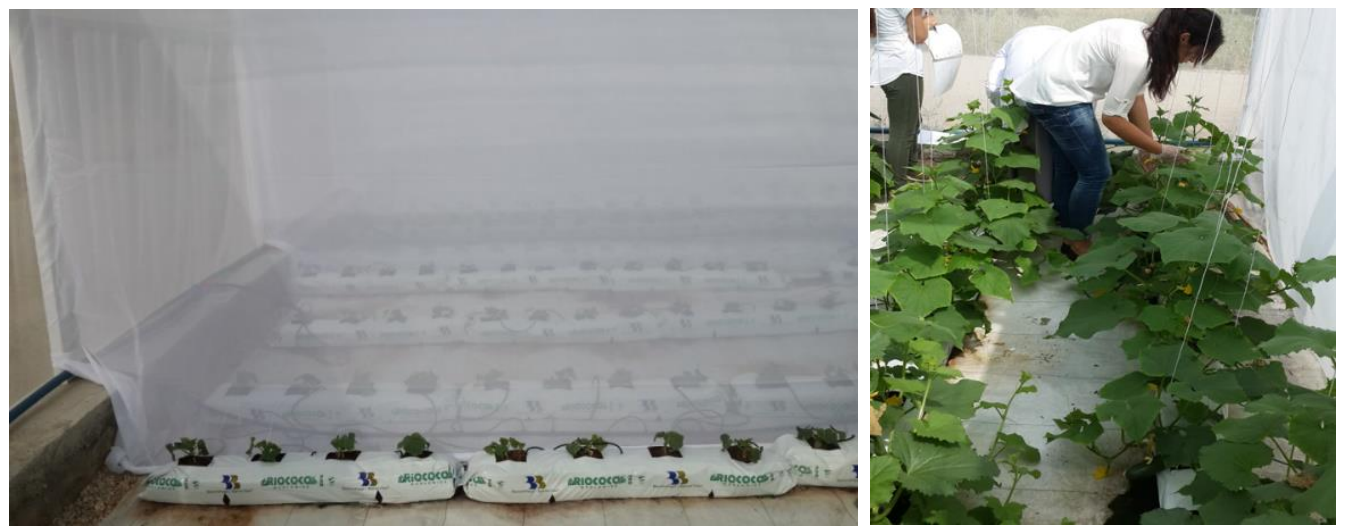

Figure 1. A view from experiment unit

\section{Statistical analysis}

The data were analyzed by the SPSS 17 statistical program (SPSS Inc., 2008) using general linear model to compare the effects of relase rates of predatory mites and time on controlling Tetranychus urticae at screenhouse conditions. ANOVA was used to compare means and Tukey's test was used to separate means.

\section{Results}

When Phytoseiulus persimilis was not released and without acaricide application, the population of Tetranychus urticae was constantly increased, and reached a peak of 141.11 motiles per leaf at week 5 and then decreased due to death of the infested cucumber plants $(\mathrm{F}=3.42 ; \mathrm{df}=4,64 ; \mathrm{P}<0.05)$ (Figures 2, 3b).

Two weeks after the predatory mite release, no $P$. persimilis motiles were recorded in the 1/5 predator:prey ratio treatment. However, at week 3 there were an average of 0.96 motiles per leaf $(\mathrm{F}=29.16$; $\mathrm{df}=4 ; \mathrm{P}<0.001)$.

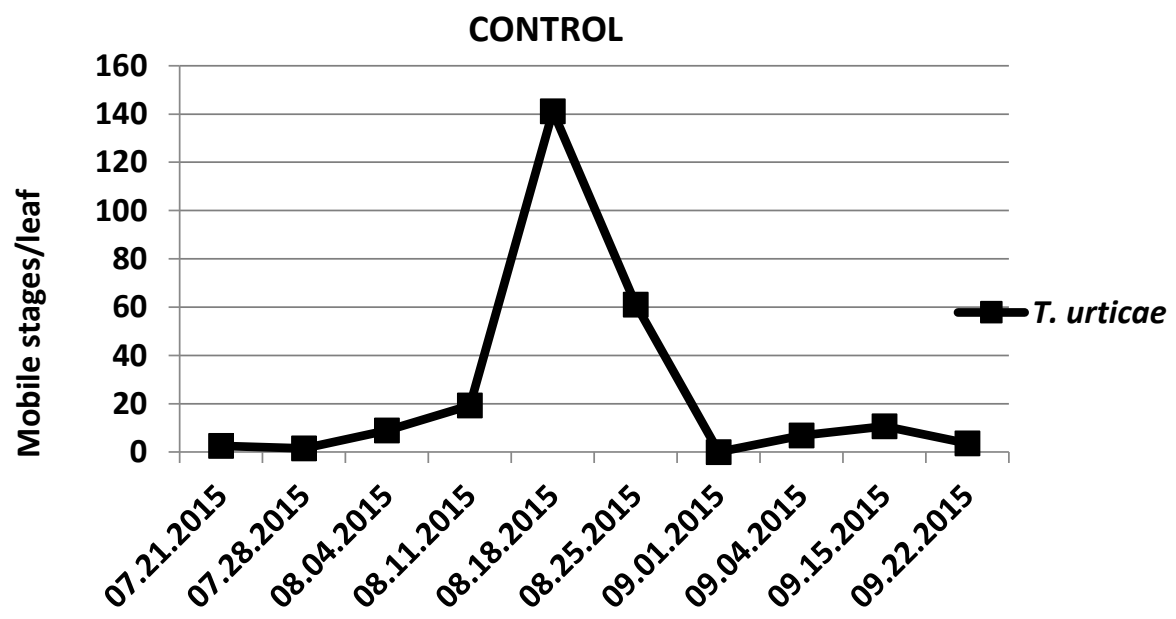

Figure 2. Tetranychus urticae two-spotted spider mite density in untreated control 
This increased to 8.07 motiles per leaf at week $4(\mathrm{~F}=10.33$; $\mathrm{df}=4 ; \mathrm{P}<0.001)$ and declined to 4 and 2 motiles per leaf at week 5 and 6 respectively and then remained at this level for the remaining 2 weeks (Figure 4). The parasitic mite T. urticae population was followed the same trend with the predator mite. It's population reached at peak of 10.66 motile per leaf at week $4(\mathrm{~F}=22.25 ; \mathrm{df}=4 ; \mathrm{P}<0.001)$ and declined to 3.33 and 2.04 motile per leaf at week 7 and 8 , respectively $(\mathrm{F}=9.92 ; \mathrm{df}=4 ; \mathrm{P}<0.001)$ (Figure 4).
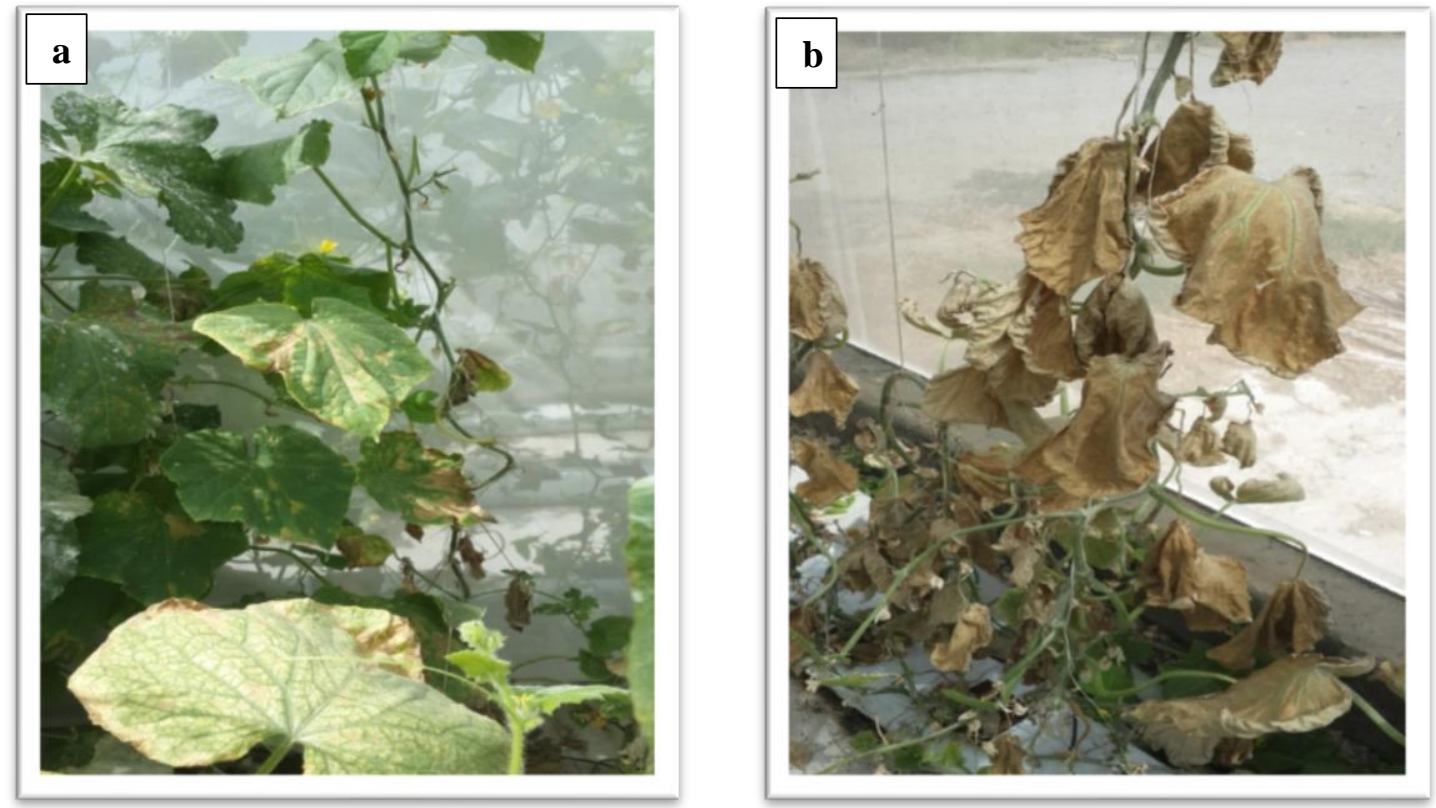

Figure 3. a. Cucumber plants in Phytoseiulus persimilis released plots $\boldsymbol{b}$. Damages caused by Tetranychus urticae in untreated control plants

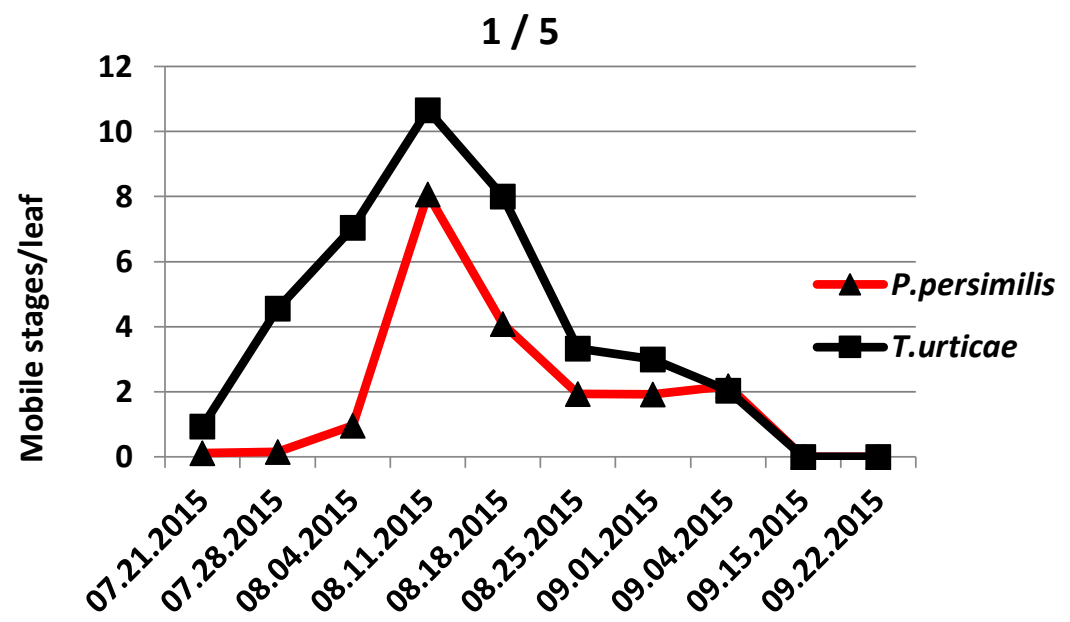

Figure 4. Tetranychus urticae two-spotted spider mite and Phytoseiulus persimilis density at 1/5 predator:prey ratio

$P$. persimilis population density increased with increase in $T$. urticae population and decreased with decrease in prey density. The data demonstrated that releases of $P$. 
persimilis at a 1:15 predator:prey ratio maintained low T. urticae populations (Figure 4). Two weeks after the predatory mite release, no $P$. persimilis motiles were recorded in the 1/15 predator:prey ratio treatment. However, at week 3 there were an average of 1.0 motiles per leaf $(\mathrm{F}=29.16$; $\mathrm{df}=4 ; \mathrm{P}<0.001)$. This increased to about 3.5 motiles per leaf at week 7 and declined to 3 and 0.5 motiles per leaf at week 8 and 9 , respectively ( $F$ $=4.88 ; \mathrm{df}=4 ; \mathrm{P}<0.01$ ) (Figure 5).

The parasitic mite $T$. urticae population was followed the parallel trend with the predator mite It's population reached at peak of 4.25 motile per leaf at week $2(\mathrm{~F}=22.11$; $\mathrm{df}=4 ; \mathrm{P}<0.001)$ and declined to $3.25(\mathrm{~F}=6.52 ; \mathrm{df}=4 ; \mathrm{P}<0.01), 1.75(\mathrm{~F}=22.11 ; \mathrm{df}=$ $4 ; \mathrm{P}<0.001), 1.0(\mathrm{~F}=3.41 ; \mathrm{df}=4 ; \mathrm{P}<0.05)$ and $0.75(\mathrm{~F}=8.59 ; \mathrm{df}=4 ; \mathrm{P}<0.001)$ motile per leaf at week $3,4,5$ and 6 , respectively. T. urticae population reached average of 1.75 motile per leaf at week 7 and declined to 1.41 and 0.0 motile per leaf at week $8(\mathrm{~F}=9.91$; $\mathrm{df}=4 ; \mathrm{P}<0.002$ ) and 9, respectively (Figure 5).

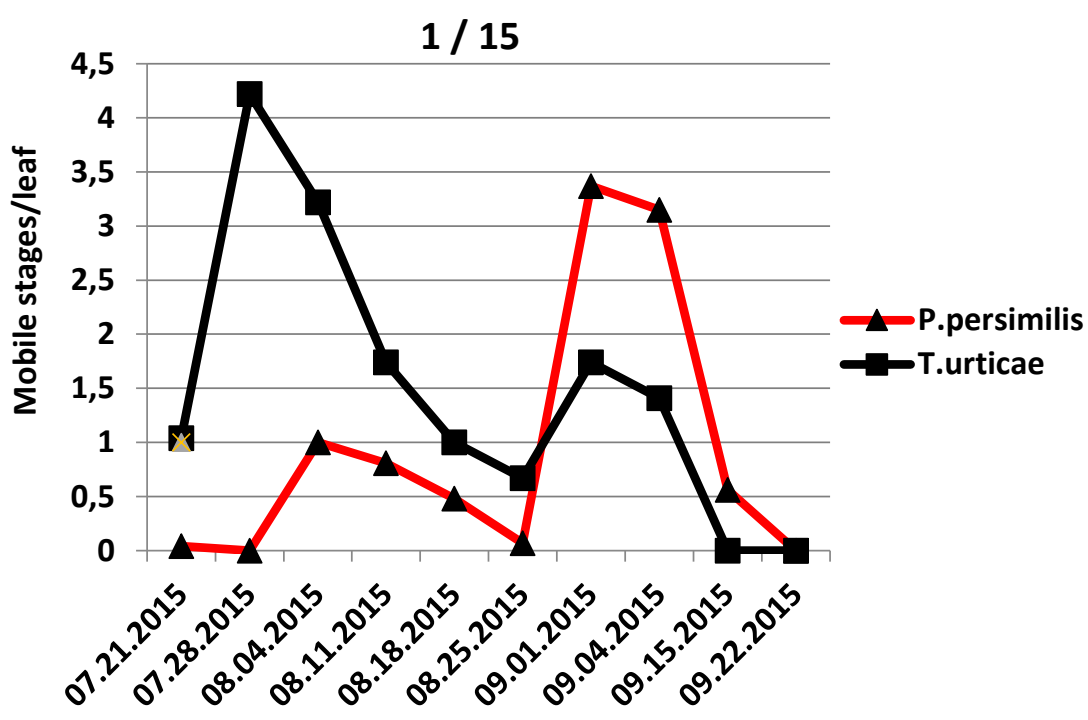

Figure 5. Tetranychus urticae two-spotted spider mite and Phytoseiulus persimilis density at 1/15 predator:prey ratio

At $1 / 30$ predator:pery ratio treatment, despite the predator population reached peak of 22.0 motiles per leaf at week $4(\mathrm{~F}=10.30$; $\mathrm{df}=4$; $\mathrm{P}<0.001)$ it did not suppress the population of $T$. urticae which reached average of 40 motiles per leaf at week $4(\mathrm{~F}=$ 22.25; $\mathrm{df}=4 ; \mathrm{P}<0.001$ ) (Figure 6). One week after predatory mite release, no $P$. persimilis motiles were recorded in the $P$. persimilis treatment. However, constant increase of $P$. persimilis observed after first week of release $P$. persimilis did not suppress T. urticae population effectively until week 5 (12.37 motiles/leaf) $(\mathrm{F}=3.42 ; \mathrm{df}=4 ; \mathrm{P}<$ 0.05). Tetranychus urticae population declined to average of 7.55 motile per leaf at week $6(\mathrm{~F}=8.59 ; \mathrm{df}=4 ; \mathrm{P}<0.003)$ then continued to decline constantly to $6.9(\mathrm{~F}=9.92 ; \mathrm{df}=$ $4 ; \mathrm{P}<0.002), 2.2(\mathrm{~F}=6.28 ; \mathrm{df}=4 ; \mathrm{P}<0.01)$ and 0 motiles per leaf at week 7.8 and 9 respectively (Figure 6).

In the acaricide treatment, $T$. urticae population reached the peak of 2.8 motile per leaf at week $3(\mathrm{~F}=6.53 ; \mathrm{df}=4 ; \mathrm{P}<0.01)$ and declined to average of 0.8 motile per leaf at week $4(\mathrm{~F}=22.25 ; \mathrm{df}=4 ; \mathrm{P}<0.001)$ than increased up to average of 1.95 motile per leaf 
at week $5(\mathrm{~F}=3.42 ; \mathrm{df}=4 ; \mathrm{P}<0.05)$. Again the population of T. urticae started to decline at week $6(\mathrm{~F}=8.59 ; \mathrm{df}=4 ; \mathrm{P}<0.003)$ (Figure 7).

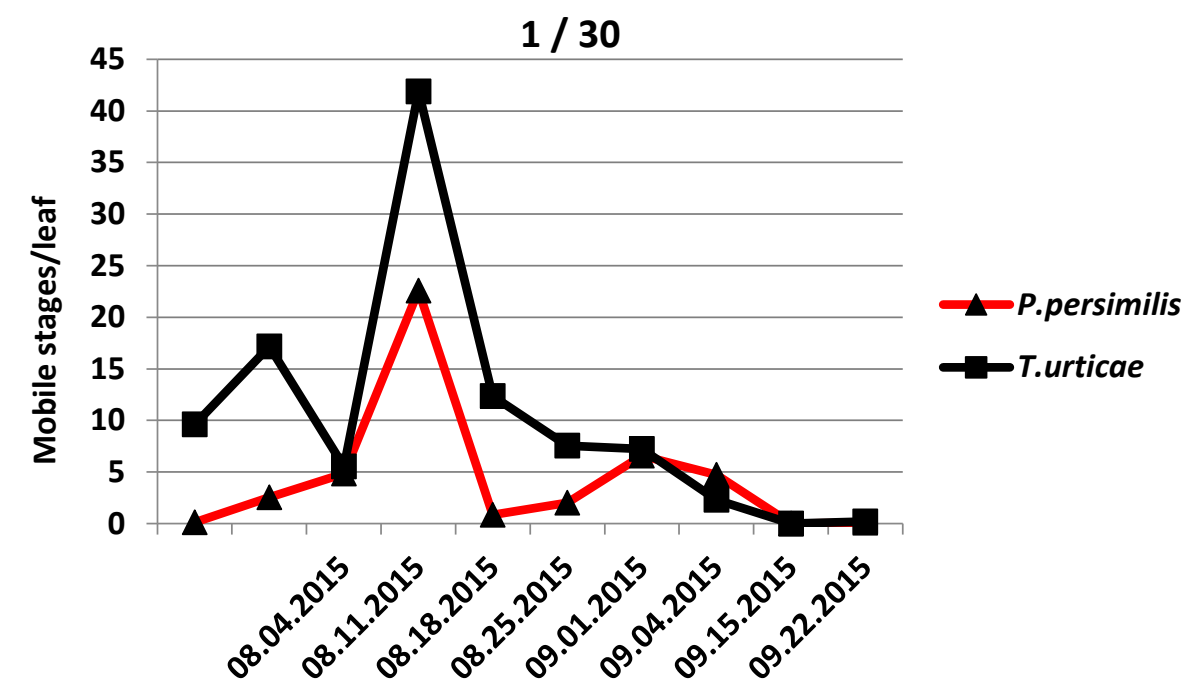

Figure 6. Tetranychus urticae two-spotted spider mite and Phytoseiulus persimilis density at 1/30 predator:prey ratio

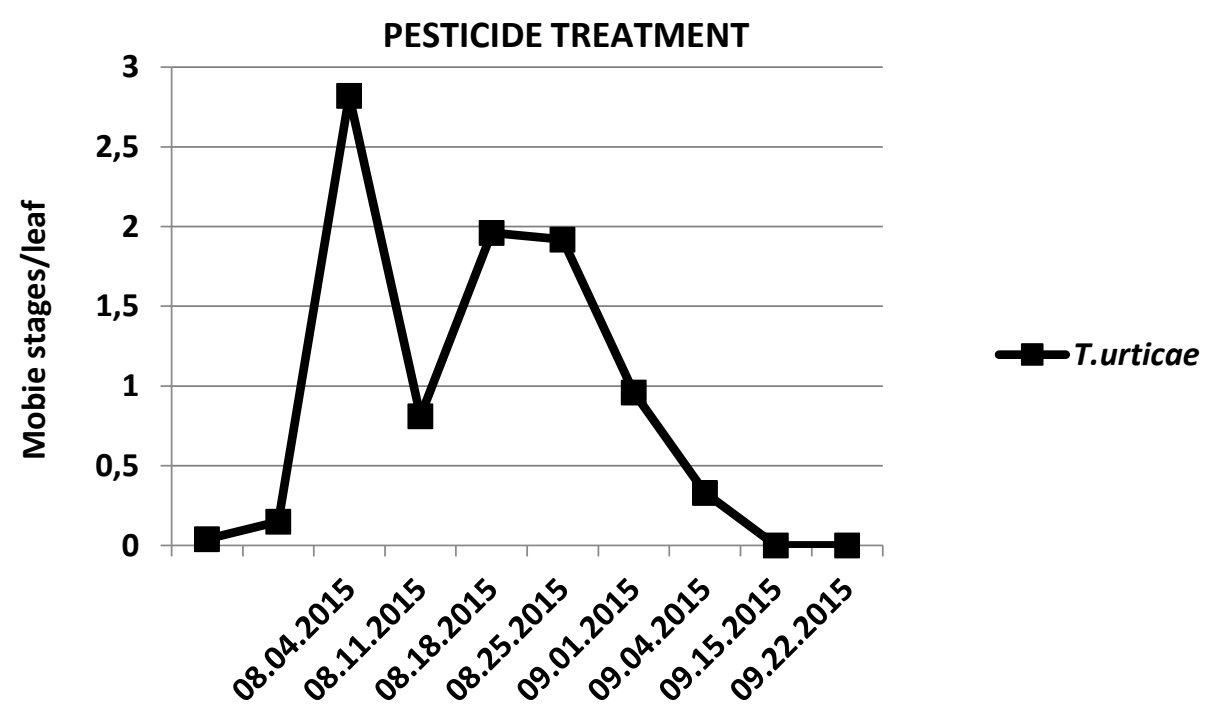

Figure 7. Tetranychus urticae two-spotted spider density in acaricide treatment

\section{Discussion}

The natural predator of two-spotted spider mites Phytoseiulus persimilis is the most widely used commercial predators for controlling mites. Having shorter development period from one generation to the next provides advantage to $P$. persimilis over the preys. However, the faster development potential of $P$. persimilis is an important factor in its success as a predator, it was reported that the initial ratio of pest to predator determines the outcome of a control program (Griffits, 2000; Lanzoni et al., 2017). Based on the 
results of the present study, population of Tetranychus urticae increased rapidly in control treatment after week 4 . The rapid population growth of $T$. urticae in the control treatment was expected, given the high biotic potential of T. urticae. Indeed prevailing conditions in protected cultivation such as greenhouse often favor the development of T. urticae (Kim and Park, 2006). The present study indicated that the potential of the predator to reduce the population of $T$. urticae determined by the predator:prey ratios at the time of predator release. At the $1 / 5$ and 1/30 predator:prey ratios, population of $T$. urticae increased, and reached the peak of 10.5 and 40.0 motiles per leaf respectively at week 4 . At these two ratios tested $P$. persimilis population increased constantly up to $4^{\text {th }}$ week of release and then began to suppress $T$. urticae population significantly $(\mathrm{p} \leq 0.05)$. On the other hand, population of $T$. urticae reached at peak of 4.25 motile per leaf at week 2 and declined to $3.25,1.75,1.0$ and 0.75 motile per leaf at week $3,4,5$ and 6 , respectively. Phytoseiulus persimilis took to reach control over T. urticae was 14 days when the pest:predator ratio is $1 / 15$. The finding of the present study demonstrated that predator:prey ratio was a determinative factor for the effective control of $T$. urticae. This finding is supported by another greenhouse study showed that Predator mite Anthoseius recki (Wainstein) (Mesostigmata: Phytoseiidae) suppressed the population of Tetranychus cinnabarinus at $1 / 30$ and $1 / 15$ predator:prey ratios effectively. However, at 1/60 predator:prey ratio the predator failed to provide effective control of the prey on strawberry plants (Şekeroğlu, 1984). Scopes (1985) reported that $P$. persimilis took to reach control over $T$. urticae was 16 days when the pest:predator ratio was 1:200, 13 days when it was $1: 100$, and 11 days when it is 1:50. This clearly demonstrates that early application is more efficient. $P$. persimilis gave effective control of $T$. urticae when it was released onto strawberry with low levels of T. urticae infestation in southeast Queensland, Australia (Waite, 1998). Bonomo et al. (1991) also reported that releases of $P$. persimilis gave effective control of T. urticae at lower density of it. Similarly Kim (2001) evaluated the effectiveness of $P$. persimilis against $T$. urticae on strawberry in five commercial greenhouses and got an excellent result by releasing the predator at a rate of $3 / \mathrm{m}^{2}$ in Korea. Spicciarelli et al. (1992) and Boom et al. (2002) recommended that phytoseiid mites give good control of $T$. urticae, if one mite is released per plant when the infestation of $T$. urticae has reached two individuals per leaf, and about $30 \%$ of the leaves are infested.

\section{Conclusion}

This study was conducted to see controlling two-spotted spider mites using $P$. persimilis at cucumber plants in screenhouse conditions in Tokat. Our results indicate that when released at 1:15 predator:prey and when $T$. urticae population are low per leaf, $P$. persimilis is able to maintain populations of $T$. urticae below damaging levels throughout a growing season (Figure $3 a$ ). It would appear that $P$. persimilis can give good control of two-spotted spider mite on cucumber plants, particularly if the predator is introduced when numbers of $T$. urticae are fairly low. What we do for growers, we arrange field days in the light of experiences and the results are shared with our producers and the stakeholders.

Acknowledgement. This work was funded by Tokat Provincial Administration. 


\section{REFERENCES}

[1] Bonomo, G., Catalano, G., Maltese, V., Sparta, S. (1991): Biological and integrated control experiment in Marsalese strawberry crops. - Informatore Agrario 47: 97-100.

[2] Boom, C. E. M., Beek, T. A., Dicke, M. (2002): Attraction of Phytoseiulus persimilis (Acari: Phytoseiidae) towards volatiles from various Tetranychus urticae-infested plant species. - Bulletin of Entomological Research 92: 539-546.

[3] Çakmak, İ., Baspinar, H., Madanlar, N. (2005): Control of the Carmine Spider Mite Tetranychus cinnabarinus Boisduval by the Predatory Mite Phytoseiulus persimilis (Athias-Henriot) in Protected Strawberries in Aydin, Turkey. - Turk. J. Agric. For. 29: 259265.

[4] Çakmak, İ., Janssen, A., Başpınar, H., Sabelis, M. (2007): Aydın ili örtü altı çilek alanlarında zararlı Tetranychus cinnabarinus'un mücadelesinde Phytoseiulus persimilis ve Neoseiulus californicus'un kullanılma olanakları. - Türkiye II. Bitki Koruma Kongresi Bildirileri.

[5] Easterbrook, M. A. (1992): The possibilities for control of two-spotted spider mite Tetranychus urticae on field-grown strawberries in the UK by predatory mites. Biocontrol Science and Technology 2(3): 235-245.

[6] Griffiths, D. A. (2000): Biological control of mite. - In: Integrated Pest and Disease Management in Greenhouse Crops, pp. 217-243.

[7] Jarosik, V. (1990): Phytoseiulus persimilis and its prey Tetranychus urticae on glashouses cucumber and pepers: Key factor related to biological control efficiency. - Acta Entomologica Bohemoslovaca 8(7): 6.

[8] Jarosik, V., Pliva, J. (1990): Efficient control of Two-spotted spider mite (Teteranychus urticae Koch.) by Phytoseiulus persimilis A.-H. On glashouses peppers. - J. Appl. Entomol. 110(3): 270-274.

[9] Kazak, C., Çölkesen, T., Zaman, K., Şekeroğlu, E. (1992): Avc1 akar Phytoseiulus persimilis' in sera koşullarında çilek üzerinde Tetranychus cinnabarinus'a karşı etkinliği. Türkiye II. Entomoloji Kongresi Bildirileri, (28-31 Ocak) Ent. Der. Yay. No: 5, Adana, 145-147.

[10] Kazak, C., Karut, K., Şekeroğlu, E. (2000): The population of dynamics and predation of Hatay strain of Phytoseiulus persimilis Athias-Henriot (Acari: Phytoseiidae) on the prey Tetranychus cinnabarinus Boisduval (Acari: Tetranychidae); effects of different initial prey and predator ratios on greenhouses cucumber. - Bull. IOBC/WPRS 23(1): 195-200.

[11] Kazak, C., Karut, K., Kasap, I., Kibritci C., Sekeroglu, E. (2002): The potential of the Hatay population of Phytoseiulus persimilis to control the carmine spider mite Tetranychus cinnabarinus in strawberry in Silifke-Icel, Turkey. - Phytoparasitica 30(5): 451-458.

[12] Kılınçer, N., Çobanoğlu, S., Has, A. (1992): Avcı Akar Phytoseiulus persimilis AnthiasHenriot (Acarina, Phytoseiidae)'in sera koşullarında çeşitli bitkilerde biyolojik mücadele kullanım olanakları üzerine araştırmalar. - Türkiye II. Entomoloji Kongresi Bildirileri. 2831 Ocak, Adana.

[13] Kim, Y. H. (2001): Control of two spotted spider mite (Tetranychus urticae) by a predatory mite (Phytoseiulus persimilis). - Technical Report, National Institute of Agricultural Science and Technology (NIAST), Korea.

[14] Kim, Y. H., Park, S. G. (2006): Optimum release times for biological control of the twospotted spider mite Tetranychus urticae Koch (Acari: Tetranychidae) by Phytoseiulus persimilis Athias-Henriot (Acari: Phytoseiidae) on the strawberry in greenhouses. Entomological Research 36: 238-244.

[15] Kısmalı, Ş., Madanlar, N., Yoldaş, Z., ve Gül, A. (1999): İzmir (Menemen)'de örtü alt1 çilek yetiştiriciliğinde kırmızı örümceklere karşı avcı akar Phytoseiulus persimilis A.-H. (Acarina: Phytoseiidae)'in uygulanma olanakları. - Türkiye 4. Biyolojik Mücadele Kongresi: 201-214. 
[16] Lanzoni, A., Martelli, R., Pezzi, F. (2017): Mechanical release of Phytoseiulus persimilis and Amblyseius swirskii on protected crops. - Bulletin of Insectology 70(2): 245-250.

[17] Loginova, E., Atanassov, N., Georgiev, G. (1987): Biological control of pests and diseases in glasshouses in Bulgaria today and in the future. - SROP/WPRS Bulletinon "İntegrated control in glasshouses" Budapest (Hungary), 101.

[18] Öncüer, C., Yoldaş, Z., Madanlar, N., Gül, A. (1994): İzmir'de sera zararlılarına karş1 biyolojik savaş uygulamaları. - Türkiye 3. Biyolojik Mücadele Kongresi Bildirileri, 395407.

[19] Scopes, N. E. A. (1985): Biological control of spider mites. - In: Hussey, N. W., Scopes, N. E. A. (eds.) Biological Pest Control: The Glasshouse Experience. Blandford Press, Poole. pp. 34-52.

[20] Spicciarelli, R. D., Battablia, D., Tranfaglia, A. (1992): Biological control of Tetranychus urticae with Phytoseiulus persimilis on strawberry. - Infomatore Agrari 48(11): 59-62.

[21] SPSS Inc. (2008): SPSS Statistics for Windows, Version 17.0. - Chicago, Illinois, USA.

[22] Şekeroğlu, E. (1984): Güney Anadolu Bölgesi Phytoseiidae akarları (Acari, Mesostigmata), biyolojileri ve çilek bitkisinde avcı akar olarak etkinliklerinin araştırılması. - Doğa Bilim Dergisi 8: 320-336.

[23] Waite, G. K. (1998): Integrated control of Tetranychus urticae in strawberries in Southeast Queensland. - Exp. Appl. Acarol. 5: 23-32.

[24] Zang, Z. Q., Sanderson, J. P. (1995): Two spotted spider mite Tetranychus urticae (Acarina: Tetranychidae) and Phytoseiulus persimilis (Acarina: Phytoseiidae) on greenhouses roses: spatial distribition and predator efficacy. - J. Econ. Entomol. 88(2): 352-357. 